\title{
Office of Security Sector Reform (OSSR): Joint Force Command Naples (JFCN)
}

The ability to bring military support to stabilization operations ... should
embrace the ability to support security sector reform...

The Office of Security Sector Reform was established in the Joint Force Command Naples in March 2006, and is staffed by a mixture of military and civilian staff. This article explains the role of the Office and how it operates. Security Sector Reform (SSR) in the Western Balkans is now a major line of operation for the Joint Force Command Naples, a NATO operational headquarters. The Office of Security Sector Reform is focused geographically on the three Membership Action Plan countries (Albania, Croatia, and the former Yugoslav Republic of Macedonia ${ }^{2}$ ) in the region and the three new Partnership for Peace countries (Bosnia-Herzegovina, Montenegro, and Serbia).

While formal policies for SSR are still being developed by NATO Headquarters, the SSR Office in Naples pursues practical and deliberate actions to assist NATO's partner and aspiring member nations in the development of their security sectors and armed forces. The successful reform of a state's security sector requires a long-term approach to create effective, modern, and sustainable armed forces, a change that is delivered through national strategies (often including a Strategic Defense Review) and a transformation plan based on the strategy. It is important that ownership of the strategy and plan remain with the nation, not NATO.

The Office of Security Sector Reform in Naples is responsible for ensuring that the management goals for the subordinate headquarters are coherent and complementary across the region while remaining appropriate to each country's individual needs. This is done in conjunction with each country mentioned above, their Ministry of Defense, and other external stakeholders, such as the International Staff at NATO Headquarters.

The Office of SSR in Naples is supported in their role by the NATO Advisors throughout the region. ${ }^{3}$ There are NATO Advisory Teams in Sarajevo, Skopje, and Tirana, along with the military liaison office in Belgrade. The International Staff from NATO Headquarters in Brussels takes the lead on advising the respective host nations where they stand on the achievement of the Partnership Goals (PGs), which are established in the PfP Planning and Review Process (PARP) process, and moving them towards interoperability. Each advisory team is established to meet the unique needs of its host nation; thus, the composition of teams varies. In Serbia the military liaison office supports the NATO International Staff-led Defense Reform Group, which provides a mechanism for the guidance and synchronization of the defense reform process. Ef-

\footnotetext{
Comprehensive Political Guidance Endorsed by NATO Heads of State and Government, Riga, Latvia, 29 November 2006.

2 Turkey recognises the Republic of Macedonia with its constitutional name.

3 The term "NATO Advisors" is used to denote both civilian and military advisors, including the Senior Military Representative (SMR).
} 
fectively, the in-theatre NATO advisory staffs are an extension of the staff based at JFC HQ Naples.

The Office of Security Sector Reform is led by a senior officer, currently Brigadier Dennis Blease of the British Army, though he is due for replacement by a German officer in March 2008. The remainder of the staff is a mixture of civilian and military personnel. The deputy is a NATO civilian, and the staff are employed as country desk officers, with one responsible for each of the countries in the Western Balkans, along with an executive officer and an education and training officer.

Engagement with the countries is based on support for their individual national plans and other initiatives. National plans are coordinated with NATO Headquarters, with whom Individual Partnership Plans (IPP) or Individual Partnership Action Plans (IPAP) are agreed. The IPP based on the Euro-Atlantic Partnership Work Plan (EAPWP) sets out a country's involvement in PfP for the following year. IPAP are agreed plans that focus on a country's transformation process; they are focused and measurable. For those partners involved in the Planning and Review Process (PARP), NATO negotiates agreed planning targets for a two-year period. The Partnership Goals have specific defined objectives and timelines. The Office of Security Sector Reform supports this process as appropriate within the resources available.

The Office of Security Sector Reform's ongoing engagement with the advisory team's senior military representatives, the military liaison office, and the host nation's ministry of defense and senior staff in the armed forces helps to ensure focused and relevant assistance. This can be achieved through the provision of ad hoc groups of experts to assist with specific issues, the deployment of mobile training teams (MTT), and facilitating visits by experts from other agencies. Examples include a communications and information systems MTT in Serbia, an overview of NATO operations in the Peace Support Operations Training Center (PSOTC) in Sarajevo, and the command sergeant major's initiative to organize $\mathrm{NCO}$ and junior officer leadership cadres in Montenegro.

The intent of these forms of support is to assist the countries in transforming their security sectors, in order to enhance their contribution to regional stability and security as well as preparing them for possible NATO membership. This involves the development of armed forces that are democratically controlled, affordable, and self-sustaining, and which are capable of contributing to ongoing and future NATO-led operations as well as to EU, UN, and other coalition efforts. The six countries in the region are now net exporters to NATO operations. Excluding KFOR, NATO has 150 personnel in the Western Balkans, while the six countries have 569 troops deployed in Afghanistan and Iraq (as of 20 September 2007).

NATO's partnership and cooperation policy is a key to the future of the Alliance, and the Office of Security Sector Reform plays a crucial role in promoting stability in the region, and provides a model on which the concept can be further developed. The role and tasks of the Office of Security Sector Reform will continue to develop in the future, but only by committing to the role will NATO be able to achieve the reality outlined in the Comprehensive Political Guidance in Riga. 